\title{
Recent advances in palaeopathology and the study of past societies in Argentina, southern South America
}

\author{
Leandro LUNA ${ }^{1 *}$, Jorge SUBY ${ }^{2}$ \\ ${ }^{1}$ CONICET, Museo Etnográfico J.B. Ambrosetti, Faculty of Philosophy and Letters, University of Buenos Aires, Buenos Aires, Argentina \\ ${ }^{2}$ INCUAPA-CONICET, Laboratory of Human Evolutive Ecology, Department of Archaeology, National University of the Centre \\ of the Province of Buenos Aires, Buenos Aires, Argentina
}

In October 2011, the symposium 'Contributions of Palaeopathology to the Study of Past Human Societies' was organized by the authors as part of the Xth Meeting of the Biological Anthropology Society of Argentina, La Plata, Argentina. The aim of the symposium was to present multidisciplinary population studies, which broadly included current theoretical and methodological perspectives. In this issue of Anthropological Science, two of the investigations presented at the symposium are included as full articles.

One of these papers (Luna and Aranda, 2014) focuses on the evaluation of the oral health of 40 individuals excavated from the Chenque I site (Lihué Calel National Park, La Pampa province, Central Argentina). This archaeological site is a hunter-gatherer cemetery intensively used during the final Late Holocene, containing a minimum of 216 individuals with very different preservation and anatomical associations. Pathological lesions such as caries, dental calculus, dental wear, abscesses, antemortem tooth loss, and periodontosis are studied. All these variables are related to mechanical stress, buccal hygiene, and infectious disease of the masticatory system. Some of the results are similar to previous findings for hunter-gatherer modes of subsistence (i.e. high prevalences of calculus and dental wear), while others show different patterns from the neighboring bioarchaeological samples of the same period (i.e. absence of caries and significant differences in antemortem tooth loss between sexes).

The other paper (Suby, 2014) presents an investigation of the variability in the expression of porotic hyperostosis and cribra orbitalia in the skulls of hunter-gatherer individuals from southern Patagonia, including paleodietary information. Contrary to previous data based on decontextualized remains, the results show higher frequencies of anemia in individuals from the Beagle Channel region, whose diets include mainly maritime resources, in relation to individuals with terrestrial diet. Infectious and nutritional causes in a biocultural context are proposed as probable explanations for the observed variability between economic strategies.

Although these articles are examples of the advance of palaeopathological studies in Argentina, many other multi-

\footnotetext{
* Correspondence to: Leandro H. Luna, CONICET, Museo Etnográfico J.B. Ambrosetti, Faculty of Philosophy and Letters, University of Buenos Aires, Moreno 350 (1091), Buenos Aires, Argentina. E-mail: lunaranda@gmail.com

Published online 26 July 2014

in J-STAGE (www.jstage.jst.go.jp) DOI: 10.1537/ase.140704
}

disciplinary investigations have focused on the health and illness of past hunter-gatherer and pastoralist populations based on new theoretical and methodological concepts. All these investigations contribute to the great challenge of increasing our knowledge of the health of human populations that inhabited southern South America in the past: for instance, enamel hypoplasia, porotic hyperostosis, cribra orbitalia and Harris lines (L'Heureux, 2000; Novellino and Gil, 2007; Gómez Otero and Novellino, 2011; Fabra and González, 2012), degenerative joint diseases and entheseal changes (Suby and Guichón, 2009; Scabuzzo, 2012), evaluations of oral health, dental size, and hypocalcification (L'Heureux, 2000; Bernal et al., 2007; Luna, 2010; Luna and Aranda, 2010; Menéndez, 2010; Flensborg, 2011; see Bernal and Luna, 2011), analyses of bone mineral density (Suby et al., 2009), paleoparasitological studies (Aranda et al., 2010; Fugassa et al., 2010), research on infectious (Guichón et al., 2009; García Laborde et al., 2010; Flensborg et al., 2013; Arrieta et al., 2014), traumatic (Gordón and Bosio, 2012; Gordón, 2013) and neoplastic diseases (Luna et al., 2008). Some paleoepidemiological and paleodemographical studies were also carried out (García Guraieb, 2006; Luna, 2006, 2012; Berón et al., 2012; Flensborg et al., 2013). Additionally, three identified skeletal collections are now under study in Argentina (Barboza et al., 2005; Bosio et al., 2012; Salceda et al., 2012).

Many of these researches, based on biocultural or bioarchaeological approaches that have developed rapidly in Argentina in the last two decades, discuss paleodietary and archaeological information from paleopathological perspectives using modern theoretical and interpretative techniques (i.e. Ortner, 2011; Grauer, 2012). Despite this recent growth of the discipline in Argentina, it is necessary to deepen the characterization and interpretation of pathological lesions, using the theoretical and methodological techniques that are now the subject of discussion at the international level. Among them, it is of major importance to recognize the complexity of bone biology based on the clinical and experimental literatures. Paleopathological research in Argentina should further enhance the interdisciplinary character of the investigations, in which numerous lines of analysis complementarily provide more robust results and interpretations. Moreover, a stronger interaction with the international scientific community and the publication of papers in high-impact journals such as Anthropological Science is needed to increase the visibility of Argentinian research. 


\section{References}

Aranda C., Araújo Silva P., Fugassa M., and Araújo A. (2010) Primeros resultados paleoparasitológicos de una muestra de entierros del Sitio Chenque I (Parque Nacional Lihué Calel, provincia de La Pampa). In: Berón M., Luna L., Bonomo M., Montalvo C., Aranda C., and Carrera Aizpitarte M. (eds.), Mamül Mapu: Pasado y Presente desde la Arqueología Pampeana. Editorial Libros del Espinillo, Ayacucho, Buenos Aires, pp. 113-122.

Arrieta M.A., Bordach M.A., and Mendonça O.J. (2014) PreColumbian tuberculosis in Northwest Argentina: skeletal evidence from Rincón Chico 21 cemetery. International Journal of Osteoarchaeology, 24: 1-14.

Barboza M.C., Ayuso M.P., Sarmiento H., and Miguel J.C. (2005) Estudio de estimadores anatómicos de la edad a la muerte en esqueletos adultos del cementerio 'La Piedad' (Rosario, Santa Fé). Revista de la Escuela de Antropología, XI: 161-168.

Bernal V. and Luna L. (2011) The development of dental research in Argentinean biological anthropology: current state and future perspectives. Homo-Journal of Comparative Human Biology, 62: 315-327.

Bernal V., Novellino P., González P., and Pérez S.I. (2007) Role of wild plant foods among Late Holocene hunter-gatherers from Central and North Patagonia (South America): an approach from dental evidence. American Journal of Physical Anthropology, 133: 1047-1059.

Berón M., Aranda C., and Luna L. (2012) Mortuary behaviour in subadults: children as active social actors in hunter-gatherer societies of the Centre of Argentina. International Journal of Childhood in the Past, 5: 51-69.

Bosio L., García Guraieb S., Luna L., and Aranda C. (2012) Chacarita Project: conformation and analysis of a modern and documented human osteological sample from Buenos Aires City. Homo-Journal of Comparative Human Biology, 63: 481-492.

Fabra M. and González C.V. (2012) Diet and oral health of populations that inhabited Central Argentina (Córdoba province) during Late Holocene. International Journal of Osteoarchaeology. DOI: 10.1002/oa.2272 (in press).

Flensborg G. (2011) Dento-alveolar lesions and palaeodietary inferences from the Paso Alsina 1 site (District of Patagones, Province Buenos Aires, Argentina). Homo-Journal of Comparative Human Biology, 62: 335-350.

Flensborg G., Martínez G., and Bayala P. (2013) Mortality profiles of hunter-gatherer societies: a case study from the Eastern transition Pampa-Patagonia (Argentina) during the Final Late Holocene. International Journal of Osteoarchaeology. DOI: 10.1002/oa.2348 (in press).

Fugassa M.H., Beltrame M.O., Sardella N.H., and Civalero M.T. (2010) Paleoparasitological results from coprolites dated at the Pleistocene-Holocene transition as source of paleoecological evidences in Patagonia. Journal of Archaeological Science, 37: 880-884.

García Guraieb S. (2006) Salud y enfermedad en cazadoresrecolectores del Holoceno tardío en la cuenca del lago Salitroso (Santa Cruz). Intersecciones en Antropología, 7: 37-48.

García Laborde P., Suby J.A., Guichón R.A., and Casali R. (2010) El antiguo cementerio de la misión de Rio Grande, Tierra del Fuego: primeros resultados sobre patologías nutricionalesmetabólicas e infecciosas. Revista Argentina de Antropología Biológica, 12: 57-69.

Gómez Otero J. and Novellino P. (2011) Diet, nutritional status and oral health in hunter-gatherers from the Central-Northern coast of Patagonia and the Chubut River lower valley, Argentina. International Journal of Osteoarchaeology, 21: 643-659.

Gordón F. (2013) Bioarchaeological patterns of violence in north Patagonia (Argentina) during the late Holocene. Implications for the study of population dynamics. International Journal of Osteoarchaeology. DOI: 10.1002/oa.2325 (in press).

Gordón F. and Bosio L.A. (2012) An experimental approach to the study of interpersonal violence in Northeastern Patagonia (Argentina), during the late Holocene. Journal of Archaeological Science, 39: 640-647.

Grauer A. (ed.) (2012) A Companion to Paleopathology. WileyBlackwell, Chichester.

Guichón R.A., Casali R., García Laborde P., Salerno M.A., and Guichón R. (2009) An interdisciplinary approach to coloniality in Tierra del Fuego (late 19th-early 20th centuries). In: Murphy M. and Klaus H. (eds.), Bioarchaeology of Contact, Colonial Encounters and Colonialism. Bioarchaeological Interpretations of the Human Past: Local, Regional, and Global Perspectives. University Press of Florida, Gainesville (in press).

L'Heureux L. (2000) Estudio comparativo de indicadores de adecuación fisiológica y salud bucal en muestras de restos humanos del Sudeste de la región pampeana. Relaciones de la Sociedad Argentina de Antropología, XXV: 51-73.

Luna L. (2006) Evaluation of uniradicular teeth for age-at-death estimations in a sample from a Pampean hunter-gatherer cemetery (Argentina). Journal of Archaeological Science, 33: $1706-1717$.

Luna L. (2010) Alternative methodological procedures in sex determination of commingled and fragmentary human remains: An example from Argentine Pampean Region. In: Weiss, K. (ed.), Trends in Physical Anthropology: 1-48. Nova Science Publishers, New York.

Luna L. (2012) Validación de métodos para la generación de perfiles de mortalidad a través de la dentición. Su importancia para la caracterización paleodemográfica. Revista Argentina de Antropología Biológica, 14 (Special Issue): 33-51.

Luna L. and Aranda C. (2010) Asociación entre cantidad de indicadores dentales de estrés metabólico y edad de muerte en el Sitio Chenque I: su variación por sexo y patrones de inhumación. In: Berón M., Luna L., Bonomo M., Montalvo C., Aranda C., and Carrera Aizpitarte M. (eds.), Mamül Mapu: Pasado y Presente desde la Arqueología Pampeana: 211-226. Editorial Libros del Espinillo, Ayacucho, Argentina.

Luna L. and Aranda C. (2014) Trends in oral pathology of huntergatherers from Western Pampas, Argentina. Anthropological Science. DOI: 10.1537/ase.140511 (in press).

Luna L., Aranda C., Bosio, L., and Berón, M. (2008) A case of multiple metastasis in late Holocene hunter-gatherers from Argentine Pampean region. International Journal of Osteoarchaeology, 18: 492-506.

Menéndez L. (2010) Patologías bucales en cráneos humanos del noreste de Patagonia: tendencias temporales en la dieta y estado de salud de las poblaciones del Holoceno-tardío del valle inferior del río Negro. Magallania, 38: 115-126.

Novellino P. and Gil A. (2007) Estrés nutricional, hipoplasia y explotación de recursos en el centro sur de Mendoza (Argentina). Intersecciones en Antropología, 8: 17-29.

Ortner D. (2011) Human skeletal paleopathology. International Journal of Paleopathology, 1: 4-11.

Salceda S., Desántolo B., García Mancuso R., Plischuk M., and Inda A.M. (2012) The 'Prof. Dr. Rómulo Lambre' Collection: An Argentinian sample of modern skeletons. Homo-Journal of Comparative Human Biology, 63: 275-281.

Scabuzzo C. (2012) Estudios bioarqueológicos de marcadores de estrés ocupacional en cazadores recolectores pampeanos del Holoceno temprano medio. Análisis de la serie esqueletal de Arroyo Seco 2. Revista Argentina de Antropología Biológica, 14: $17-31$.

Suby J. (2014) Porotic hyperostosis and cribra orbitalia in human remains from Southern Patagonia. Anthropological Science (in press).

Suby J. and Guichón R. (2009) Diet, nutrition and paleopathology in Southern Patagonia. Some experiences and perspectives. International Journal of Osteoarchaeology, 19: 328-336.

Suby J., Guichón R., Cointry G., and Ferretti J.L. (2009) Bone mineral density of human remains with pQCT and DEXA. Journal of Taphonomy, 7: 29-45. 